\title{
Morphoanatomical adjustments of Tibouchina clavata (Melastomataceae) in ombrophilous forest and restinga forest
}

João Carlos Ferreira Melo Jr ${ }^{1}$, Maick William Amorim ${ }^{1}$, Igor Abba Arriola ${ }^{1}$, Jessica Stefani Dirksen ${ }^{1}$ e Fernando Andreacci ${ }^{2}$

\author{
${ }^{1}$ Universidade da Região de Joinville, SC, Brasil \\ jcmelo_wood@hotmail.com; maickwamorim@gmail.com; igor_abba@hotmail.com; jessica.s.dirksen@gmail.com \\ ${ }^{2}$ Universidade do Vale do Itajaí, SC, Brasil \\ fandreacci@gmail.com
}

\begin{abstract}
:
Structural adjustments in plants may occur in response to environmental constraints, which may influence plant growth and development, as well as patterns of species coexistence. Of wide geographical distribution in the Atlantic Forest, Tibouchina. clavata presents structural variations in the ecosystems in which it occurs. The present study aimed to evaluate the adaptive responses of Tibouchina clavata (Melastomataceae) occurring in two forest formations governed by different environmental conditions. Ten leaves of ten individuals were collected in each formation, for a total of $n=100$ per area as were stem samples, for measuring architectural, morphological and foliar traits. Environmental variables considered included edaphic nutrition, water availability and light radiation. The phenotypic plasticity index was calculated for each trait. Morphoanatomical traits varied among populations with greater emphasis on plant height and stem diameter, in contrast to the lower variation observed for leaf traits. Foliar morphoanatomy met the expected pattern for plants that grow under conditions of greater luminosity. Greater development of the aerial system (height and diameter of the stem) was observed in the plants of the ombrophilous forest, indicating that this growth is related to the soil fertility and water availability. The phenotypic plasticity index indicates low plasticity for Tibouchina clavata in the geographic distribution studied.
\end{abstract}

Keywords: structural adjustments. functional traits. rain forest. biodiversity conservation 


\section{Introduction}

Melastomataceae is one of the largest angiosperm families in the world (Penneys and Judd, 2011), with about 4,500 species distributed among 150 genera (Renner et al., 1993). They occur preferentially in the tropical and subtropical regions (Clausing and Renner, 2001), and in Brazil, they extend from the Amazon to the state of Rio Grande do Sul, with more than 1,500 species in 68 genera having been recorded (Romero and Martins, 2002). The species range in life form from being herbaceous to shrubby, and with fewer trees, climbers and epiphytes (Romero, 1996; 2002). They occupy open and forest formations, and especially edge environments, and stand out as potential indicators of anthropic disturbance (Lorenzi, 1992). A total of 130 species in 13 genera have been recorded for the state of Santa Catarina, with Miconia Ruiz \& Pav., Leandra Raddi and Tibouchina Aubl. being the most represented genera (BFG, 2015).

Tibouchina Aubl. is the only genus of Melastomataceae with an exclusively Neotropical distribution, and has its greatest diversity in the Andean and Brazilian regions (Todzia and Almeda, 1991; Clausing and Renner, 2001). Of the 350 extant species of Tibouchina, approximately 129 occur in Brazil (Guimarães, 2015; Freitas et al., 2012), of which only 25 occur in Santa Catarina state (Wurdack, 1962).

The species Tibouchina clavata (Pers.) Wurdack., commonly known as orelha-de-onça (ear of the jaguar) (Prudente et al., 2012), is found in different Atlantic Forest formations, including associated vegetation such as restingas, in the states of Rio de Janeiro, São Paulo, Paraná and Santa Catarina (Carrasco, 2003; Mantovani, 1992; Mendonça et al., 1992; Pompéia et al., 1989; Romero and Monteiro, 1994, 1995; Reis-Duarte, 2004; Zamith and Scarano, 2004; Guimarães, 2015; Melo Júnior and Boeger, 2015).

Due to the wide distribution of this species in Brazil, it is believed that it possess structural variation in response to the different environments that it inhabits, which enables the ecological functional studies to be better understood to better understand its adaptive strategies. Ecological studies with species of Melastomataceae have shown traits that have been adjusted in response to abiotic conditions. Boeger et al. (2008), working with Miconia sellowiana in four different phytogeographic formations, observed higher values of leaf area, specific leaf area and leaf mass under conditions of higher water content and lower intensity of light radiation. In a study with Tibouchina clavata occurring in two restinga formations, Amorim and Melo Júnior (2017) also observed an increase in mass (fresh and dry), leaf area and specific leaf area with increasing water availability in the environment.

In order to better understand the plastic responses of species of the family Melastomataceae distributed in different geographical environments, the present study analyzed the occurrence of morphoanatomical differences in populations of Tibouchina clavata in two vegetation formations within the Atlantic Forest domain with contrasting environmental conditions of soil, light and water: resting a forest and ombrophilous forest. It is hypothesized that: a) the scarcity of water and soil nutrients associated with high light radiation in the restinga environment will induce xeromorphic structural responses; and b) environmental conditions opposite to those reported in the first hypothesis will be precursors of mesomorphic structural responses in the forest population.

\section{Material and Methods}

\section{Study area}

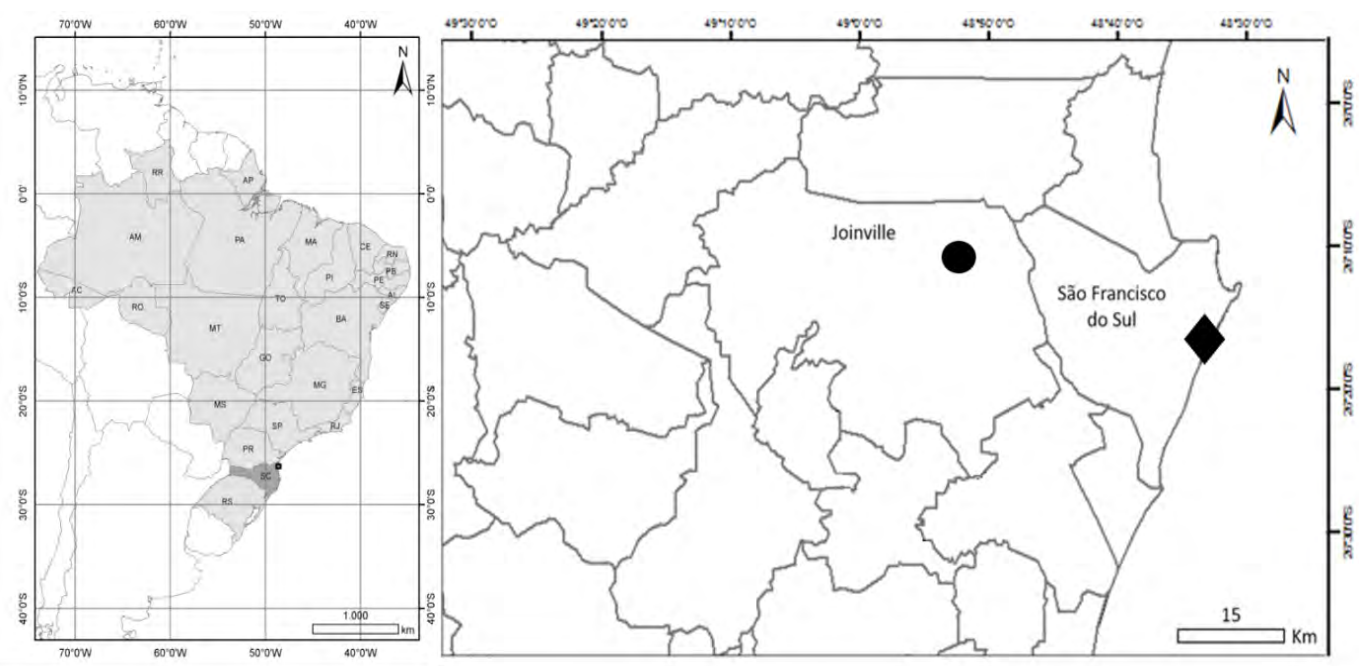

Figure 1. Spatial location of the study (collection) areas of Tibouchina clavata (Melastomataceae) in the state of Santa Catarina, Brazil. 


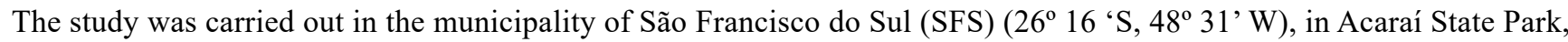
and in the municipality of Joinville (JLLE) $\left(26^{\circ} 15^{\prime} \mathrm{S}, 48^{\circ} 51^{\prime}\right.$ ') on the Campus of the Universidade da Região de Joinville, both in the state of Santa Catarina (Figure 1). The population present in SFS is about two kilometers distant from the Atlantic Ocean and occurs in a restinga forest on sandy Ferrihumiluvic Spodosol + Haplic Organosol type soil of hydromorphic nature (Melo Júnior and Boeger, 2015). The population studied at JLLE occupies a fragment of dense ombrophilous lowland forest on Haplic Cambisol type soil (IPPUJ, 2012). The climate of both areas is humid temperate with a hot summer and no defined dry seasen; it is classified as Cfa according to Köppen (1948). The average annual temperature at SFS is $21.2{ }^{\circ} \mathrm{C}$ and the mean annual rainfall is $1830 \mathrm{~mm} /$ year, while at JLLE the average annual temperature is $21.1^{\circ} \mathrm{C}$ and the average annual rainfall is $1706 \mathrm{~mm} /$ year (Climate -Data, 2017).

\section{Collection and analysis of plant material}

Ten individuals of Tibouchina clavata were selected in each study population for a total sample of 20 individuals. Plant height and stem diameter were measured for each individual, and twenty fully-expanded leaves from the third and fourth nodes from the branch apex, and without lesions caused by herbivores, that were exposed to the sun were collected from each individual.

Of this total, 10 leaves from each plant were saturated in water for $12 \mathrm{~h}$ and used to measure the fresh mass ( $\mathrm{g}$ ) with an analytical balance. The leaves were then dehydrated in an air circulation oven at $70{ }^{\circ} \mathrm{C}$ for 72 hours to determine the dry mass (g), again with analytical balance. Succulence $\left(\mathrm{g} . \mathrm{cm}^{-2}\right)$ was determined from FM - DM / LA, where: FM (fresh mass), DM (dry mass) and LA (leaf area). Leaf area $\left(\mathrm{cm}^{2}\right)$ was obtained by means of scanned images made using a flatbed scanner coupled with Sigma Scan Pro software (version 5.0, SPSS Inc., Chicago IL, USA). The specific leaf area (SLA, $\mathrm{cm}^{2} . \mathrm{g}^{-1}$ ) was calculated as the ratio between leaf area and dry mass (Witkowski and Lamont, 1991). The remaining 10 leaves from each plant were fixed in FAA 70\% (solution of ethanol 70\%, formalin and acetic acid - 9:1:1) (Johansen, 1940) for the anatomical analyses. Permanent histological preparations were made from paraffin-embedded mid sections of leaves sectioned at about $10 \mu \mathrm{m}$ on a Leica RM2125 rotating microtome. Sections were then dewaxed, stained with basic fuchsine and mounted on synthetic resin (Paiva et al., 2006). Leaf tissue biometry was performed using image capture in Dino-Eye software (Anmo Electronica Corporation) coupled to an Olympus CX 200 photomicroscope. The anatomical traits evaluated are: adaxial and abaxial epidermal thickness + cuticle $(\mu \mathrm{m})$, palisade parenchyma $(\mu \mathrm{m})$ and spongy parenchyma $(\mu \mathrm{m})$.

\section{Environmental variables}

For nutritional characterization of the forest soils, 10 samples at $15 \mathrm{~cm}$ of depth were collected in each environment and combined to obtain a single composite sample for each forest. Soil chemistry analysis was carried out according to standard methodology (EMBRAPA, 2013) at the Laboratory of Soil Analysis of EPAGRI. Soil water availability in each forest was estimated by gravimetric moisture taken in 10 soil samples (EMBRAPA, 2013). Photosynthetically active radiation (PAR) was determined from 10 measurements made over the canopy of each individual plant with a luxmeter (Li-250A LICOR, USA).

\section{Statistical analysis}

Means and respective standard deviations, based on 100 measurements per population of Tibouchina clavata for each biological trait, were calculated for all morphoanatomical traits, as well for environmental variables with replicates. The mean values of traits and environmental variables were compared by Student's t-test, with significance level of 5\% (Zar, 1999), in R software (Borcard et al., 2011). The amplitude of structural responses, for each morphoanatomical trait, was measured by means of the phenotypic plasticity index (IPF) was calculated as: IPF = maximum mean - minimum mean / maximum mean (Valladares et al., 2006).

\section{Results}

The soil chemistry analysis (Table 1) showed that both areas possessed low-acidic soil. In the ombrophilous forest soil, the levels of potassium $(\mathrm{K})$, calcium $(\mathrm{Ca})$, Magnesium $(\mathrm{Mg})$, potential acidity $(\mathrm{H}+\mathrm{Al})$, sum of bases $(\mathrm{SB})$, cation exchange capacity (CEC) base saturation (BS) and organic matter (OM) were higher than those obtained for the restinga forest soil, which had a higher value for only phosphorus content (P). Soil water availability was twice as high in the ombrophilous forest compared to restinga forest. Although light radiation incident on plants was higher in the restinga forest.

All morphoanatomical traits analyzed, except for succulence, differed significantly between the two populations of Tibouchina clavata (Table 2). The morphological trait that exhibited the greatest difference between populations was total plant height, with that of individuals of the ombrophilous forest reaching $240 \%$ of that for individuals of the restinga forest. Stems with greater diameter were also recorded for the ombrophilous forest plants. The remaining foliar traits, both morphological and 
anatomical, had higher values for plants inhabiting the restinga forest, such as greater leaf area, fresh and dry mass, specific leaf area and tissue thickness. In both environments, the palisade parenchyma was more developed than the spongy parenchyma, with palisade/spongy ratios of 1.4:1 and of 1.8:1 in the restinga forest and ombrophilous forest environments, respectively.

Table 1 - Mean values of soils nutrition variables, water availability and photosynthetically active radiation for restinga forest and ombrophilous forest environments. Values of water availability and PAR are represented by means \pm standard deviations and, for these variables, the different letters in the same row indicate a statistical difference $(\mathrm{p}<0.05)$.

\begin{tabular}{|c|c|c|}
\hline \multirow[b]{2}{*}{ Environmental variable } & \multicolumn{2}{|c|}{ Forest } \\
\hline & restinga & $\begin{array}{c}\text { ombrophi- } \\
\text { lous }\end{array}$ \\
\hline $\mathrm{pH}$ & 5,40 & 5,20 \\
\hline $\mathrm{P}\left(\mathrm{mg} \cdot \mathrm{dm}^{-3}\right)$ & 6,40 & 4,80 \\
\hline $\mathrm{K}\left(\mathrm{mmolc} \cdot \mathrm{dm}^{-3}\right)$ & 14,00 & 34,00 \\
\hline $\mathrm{Ca}\left(\mathrm{mmolc} \cdot \mathrm{dm}^{-3}\right)$ & 1,00 & 3,00 \\
\hline $\operatorname{Mg}\left(\right.$ mmolc.dm $\left.{ }^{-3}\right)$ & 0,10 & 1,70 \\
\hline $\mathrm{H}+\mathrm{Al}\left(\mathrm{mmolc} \cdot \mathrm{dm}^{-3}\right)$ & 1,50 & 3,30 \\
\hline $\mathrm{SB}\left(\mathrm{mmolc} \cdot \mathrm{dm}^{-3}\right)$ & 0,83 & 4,78 \\
\hline CEC $\left(\right.$ mmolc.dm $\left.{ }^{-3}\right)$ & 2,67 & 8,08 \\
\hline BS (\%) & 43,93 & 59,20 \\
\hline MO $\left(\mathrm{g} \cdot \mathrm{dm}^{-3}\right)$ & 0,90 & 1,60 \\
\hline Water availability (g) & $0,72^{\mathrm{b}} \pm 0,28$ & $1,58^{a} \pm 0,12$ \\
\hline $\begin{array}{l}\text { Photosynthetically active radiation (PAR, } \\
\left.\mu \mathrm{mol} \mathrm{m} \mathrm{m}^{-2} \mathrm{~s}^{-1}\right)\end{array}$ & $\begin{array}{c}1.290^{\mathrm{a}} \pm \\
139,26\end{array}$ & $\begin{array}{c}1.147^{\mathrm{b}} \pm \\
100,61\end{array}$ \\
\hline
\end{tabular}

Table 2 - Comparative analysis of plant and leaf morphology of Tibouchina clavata (Melastomataceae) in restinga forest and ombrophilous forest environments. Values represent means \pm standard deviations. Different letters on the same line indicate a statistical difference $(\mathrm{p}<0.05)$.

\begin{tabular}{l|c|c}
\hline \multirow{2}{*}{ Trait } & \multicolumn{2}{c}{ Forest } \\
\cline { 2 - 3 } & restinga & ombrophilous \\
\hline Plant height $(\mathrm{cm})$ & $0,91^{\mathrm{b}} \pm 0,20$ & $2,19^{\mathrm{a}} \pm 0,18$ \\
\hline Stem diameter $(\mathrm{cm})$ & $7,35^{\mathrm{b}} \pm 1,39$ & $8,75^{\mathrm{a}} \pm 0,18$ \\
\hline Fresh leaf mass $(\mathrm{g})$ & $0,95^{\mathrm{a}} \pm 0,27$ & $0,71^{\mathrm{b}} \pm 0,37$ \\
\hline Dry leaf mass $(\mathrm{g})$ & $0,32^{\mathrm{a}} \pm 0,08$ & $0,29^{\mathrm{b}} \pm 0,08$ \\
\hline Leaf area $\left(\mathrm{cm}^{2}\right)$ & $21,69^{\mathrm{a}} \pm 5,16$ & $17,87^{\mathrm{b}} \pm 5,78$ \\
\hline Specific leaf area $\left(\mathrm{cm}^{2} / \mathrm{g}^{-1}\right)$ & $68,20^{\mathrm{a}} \pm 11,60$ & $62,66^{\mathrm{b}} \pm 15,11$ \\
\hline Succulence $\left(\mathrm{g} . \mathrm{cm}^{-2}\right)$ & $0,001^{\mathrm{a}} \pm$ & $0,001^{\mathrm{a}} \pm 0,0007$ \\
\hline Adaxial epidermis + cuticle $(\mu \mathrm{m})$ & $23,19^{\mathrm{a}} \pm 2,66$ & $15,55^{\mathrm{b}} \pm 2,92$ \\
\hline Abaxial epidermis + cuticle $(\mu \mathrm{m})$ & $9,83^{\mathrm{a}} \pm 1,21$ & $8,39^{\mathrm{b}} \pm 1,73$ \\
\hline Palisade parenchyma $(\mu \mathrm{m})$ & $76,47^{\mathrm{a}} \pm 12,26$ & $73,33^{\mathrm{b}} \pm 8,72$ \\
\hline Spongy parenchyma $(\mu \mathrm{m})$ & $54,45^{\mathrm{a}} \pm 11,58$ & $38,98^{\mathrm{b}} \pm 5,31$ \\
\hline
\end{tabular}

The phenotypic plasticity index (IPF), calculated to evaluate the plastic potential of Tibouchina clavata, showed that this species has a low capacity for plasticity with regard to its geographic distribution in restinga and ombrophilous forests, except for the trait of total plant height, for which the IPF was considered moderate. When the populations were analyzed separately, the IPF exhibited greater intrapopulation variation for traits of architecture and foliar morphology in the restinga forest en- 
vironment, whereas greater intrapopulation variation in anatomical traits was exhibited in the ombrophilous forest (Table 3).

Table 3 - Phenotypic Plasticity Index (IPF) of morphoanatomic traits of Tibouchina clavata (Melastomataceae) in restinga forest and ombrophilous forest environments.

\begin{tabular}{l|c|c|c}
\hline \multirow{2}{*}{ Trait } & \multicolumn{3}{c}{ IPF } \\
\cline { 2 - 4 } & $\begin{array}{c}\text { restinga } \\
\text { forest }\end{array}$ & $\begin{array}{c}\text { ombrophi- } \\
\text { lous forest }\end{array}$ & both forest \\
\hline Plant height $(\mathrm{cm})$ & 0,52 & 0,20 & 0,58 \\
\hline Stem diameter $(\mathrm{cm})$ & 0,45 & 0,50 & 0,16 \\
\hline IPF average & $\mathbf{0 , 4 6}$ & $\mathbf{0 , 4 5}$ & $\mathbf{0 , 3 7}$ \\
\hline Fresh leaf mass $(\mathrm{g})$ & 0,59 & 0,53 & 0,25 \\
\hline Dry leaf mass $(\mathrm{g})$ & 0,60 & 0,54 & 0,11 \\
\hline Leaf area $\left(\mathrm{cm}^{2}\right)$ & 0,57 & 0,37 & 0,18 \\
\hline Specific leaf area $\left(\mathrm{cm}^{2} \cdot \mathrm{g}^{-1}\right)$ & 0,64 & 0,53 & 0,08 \\
\hline Succulence $\left(\mathrm{g} . \mathrm{cm}^{-2}\right)$ & 0,51 & 0,26 & 0,03 \\
\hline IPF average & $\mathbf{0 , 5 8}$ & $\mathbf{0 , 4 4}$ & $\mathbf{0 , 1 3}$ \\
\hline $\begin{array}{l}\text { Adaxial epidermis }+ \text { cuticle } \\
(\mu \mathrm{m})\end{array}$ & 0,37 & 0,44 & 0,33 \\
\hline $\begin{array}{l}\text { Abaxial epidermis }+ \text { cuticle } \\
(\mu \mathrm{m})\end{array}$ & 0,39 & 0,45 & 0,15 \\
\hline Palisade parenchyma $(\mu \mathrm{m})$ & 0,52 & 0,54 & 0,04 \\
\hline Spongy parenchyma $(\mu \mathrm{m})$ & 0,40 & 0,64 & 0,28 \\
\hline IPF average & $\mathbf{0 , 4 2}$ & $\mathbf{0 , 5 1}$ & $\mathbf{0 , 2 0}$ \\
\hline
\end{tabular}

\section{Discussion}

Soil fertility differed distinctly between the restinga and ombrophilous forests, and was directly related to the sum of exchangeable bases and the degree of the release of assimilable nutrients that, due to one variable or the other, indicate conditions of soil fertility. The higher cation exchange capacity (CEC) observed in ombrophilous forest soil indicates a greater contribution of nutrients released over time to the plants, since it characterizes the amount of cations that a soil is able to retain per unit weight or volume, which influences the availability of nutrients (Sibaldelli et al., 2015) for plants (Chaves et al., 2004). Organic matter $(\mathrm{OM})$ plays an important role in vegetation dynamics and is considered the main indicator of soil quality (LAL, 2004). Variation in OM is controlled by rates of deposition, decomposition and renewal of residues, which occur dynamically (Mulvaney et al., 2010). The higher OM value observed in ombrophilous forest soil indicates the better quality of this soil, which is reflected in the higher content of nutrients found in it.

Thus, the ombrophilous forest soil is eutrophic (fertile, $\mathrm{V}>50 \%$ ), while the restinga forest soil is considered dystrophic (low fertility, $\mathrm{V}<50 \%$ ) and accompanied by low levels of $\mathrm{Ca}, \mathrm{Mg}$ and $\mathrm{K}$ (Ronquim, 2010). A lower $\mathrm{V} \%$ indicates that the negative charges of soil colloids are adsorbing more $\mathrm{H}+$ and $\mathrm{Al}^{3+}$, and a small amount of exchangeable cations $\left(\mathrm{K}^{+}, \mathrm{Ca}^{2+}\right.$, $\mathrm{Mg}^{2+}$ ). In this condition, the soil will be acidic and may contain a level of $\mathrm{Al}^{3+}$ toxic to the plant (Lopes and Guilherme, 2004). Dystrophic soils are generally characterized by low nutrient availability and low water availability, while eutrophic soils are commonly associated with higher fertility and water availablity (Prado, 1995).

Soil temperature and humidity are factors related to climate that also influence the availability of potassium in the soil, since elevation in ambient and soil temperature increases the diffusion of potassium by the soil and thus also the absorption by plants (Amorim, 2014). An increase in soil water availability also favors a higher absorption of potassium by increasing the rate of displacement of this nutrient to the roots (Ernani et al., 2007). Thus, the higher water availability in ombrophylous forest soil suggests a greater availability of potassium to the plants, which, after nitrogen, is most needed macronutrient for plant development (Amorim, 2014).

Of equal importance is the lower value of $\mathrm{Mg}$ obtained in restinga forest, which can be an important predictor of lower aerial system development in Tibouchina clavata. This is because this nutrient is not restricted to the maintenance of the configuration of chlorophyll, but also acts in activation of several enzymes responsible for plant body development (Epstein and Bloom, 2006). 
On the one hand, although the leaf morphoanatomical traits exhibited by Tibouchina clavata varied between populations, they generally reflect the expected structural pattern of development for plants in environments with greater light availability (Pugnaire and Valladares, 2006). On the other hand, plant architecture, represented by the traits of total plant height and stem diameter, constitutes the main structural adjustment that distinguishes the studied populations.

Total plant height is a trait that varies widely, and is positively associated with soil water availability (Jaleel et al., 2009). Studies carried out with arboreal restinga species by Bachtold and Melo Júnior (2015), Silva et al. (2016), Silva and Melo Júnior (2016) and Amorim and Melo Júnior (2017), recorded an increase in plant height in association with higher soil water availability in soils with higher organic matter content. The same pattern was reported for tree species of the Mediterranean climate, whose growth was favored by a greater supply of water in the environment and, in contrast, reduced or halted by water scarcity (Granda et al., 2013). In sandy soils, with low natural fertility and high water restriction, such as restinga soils, plant height is affected by decreased cell growth (Jaleel et al., 2009). However, even in low-fertility sandy soils, topographic soil conditions favoring organic matter accumulation and increased soil water retention can produce differences in plant architecture (Santos et al., 2017), such as has been observed for some woody restinga species (Melo Júnior and Boeger, 2017). Plants with greater investment in height are more adept at capturing light, and using it effectively in photosynthetic production (Nishio, 2000), indicating that such investment represents a central strategy in the ecology of plants (Moles et al., 2009). However, this increase in height also influences water transport, mainly due to increased transport distance and the greater difficulty of ascending water in tall trees, due to greater gravitational force (Bucci et al., 2005). Thus, the difficulty of transporting water would be directly proportional to plant height and would be aggravated in environments where there is less water availability (Ryan et al., 2006), which explains the reduced height of in Tibouchina clavata in restinga forest soil. In this regard, the adaptation of Tibouchina clavata to the forest environments studied seems to reflect a conflict between safety and efficiency of water transport (Baas et al., 2004), since although benefiting the photosynthetic mechanism, greater plant height may decrease the safety of hydraulic conductivity, especially in xeric environments (Gleason et al., 2016).

The structural variation observed in the phenotypic plasticity index when the populations are considered separately, indicates the amplitude of interspecific variation that Tibouchina clavata exhibits in its morphoanatomical traits. This variation allows this species to optimize the resources available in the environment and thus influence its consequent investment in growth, as in the case of individuals inhabiting the ombrophylous forest, or in leaf maintenance, as in the case of individuals inhabiting the restinga forest. The presence of a thicker epidermis, of a more developed palisade parenchyma than spongy parenchyma and a greater content of leaf dry mass in individuals of restinga forest, gives them a more xeromorphic condition (Fahn and Cutler, 1992). This is reinforced by the greater investment in mechanical tissues, as indicated by the higher SLA value (Turner, 1994), which consequently increases leaf hardness and longevity (Edwards and Sanso, 2000). The restingas are characterized as environments that offer more restrictive conditions to the plant development (Araujo, 2000), such as reduced water availability and low soil fertility, as found in the restinga forest in this study, which should influence resource conservation strategies such as leaf longevity, considering the high cost for the production of new structures (Rosado and Mattos, 2010). In contrast, the better conditions offered by the ombrophylous forest allows plants to maximize the resources allocated to body development, thus resulting in greater height and stem diameter.

\section{Conclusion}

The results obtained in the present study corroborate the initial hypotheses since more xeromorphic characteristics were recorded in the population of Tibouchina clavata in the restinga forest, which possesses conditions of greater nutritional deficiency and water scarcity than the ombrophilous forest. Despite this finding, the leaf morphoanatomical pattern in both forests is as would be expected for conditions of greater light exposure. The most contrasting difference between the two populations of Tibouchina clavata is in plant architecture, as represented by total plant height and stem diameter, traits with development proportional to the supply of water and soil nutrients. Under these habitat conditions the species has low plasticity for most of the traits evaluated, except for those reflecting the overall development of the plant body, represented by its architecture.

\section{References}

AMORIM MB. Métodos de avaliação da disponibilidade de potássio para as plantas em solos do Rio Grande do Sul [dissertação]. RIO GRANDE DO SUL: Ciências do Solo, Universidade Federal do Rio Grande do Sul/ UFRGS; 2014. 99p.

AMORIM MW, MELO JÚNIOR JCF. Plasticidade morfoanatômica foliar de Tibouchina clavata (Pers.) Wurdack (MELASTOMATACEAE) ocorrente em duas formações de restinga. Rodriguésia. 2017; 68(2):545-555. 
ARAUJO DSD. Análise florística e fitogeográfica das restingas do Estado do Rio de Janeiro [tese]. Rio de Janeiro: Universidade Federal do Rio de Janeiro/RJ. 2000.

BAAS P, EWERS FW, DAVIS SD, WHEELER EA. Evolution of xylem physiology. In: Poole I, Hemsley A, editors. Evolution of plant physiology. London: Elsevier Academic Press; 2004. p. 273-295.

BACHTOLD B, MELO JÚNIOR JCF. Plasticidade morfológica de Calophyllum brasiliense Camb. (Calophyllaceae) em duas formações de restinga no sul do Brasil. Acta Biológica Catarinense. 2015; (2): 21-32.

BFG, 2015. Brazil Flora Group. Growing knowledge: an overview of Seed Plant diversity in Brazil. Rodriguésia. 2015; 66(4):1085-1113.

BOEGER MRT, GLUZEZAK RM, PIL MW, GOLDENBERG R, MEDRI M. Variabilidade morfológica foliar de Miconia sellowiana Naudin (Melastomataceae) em diferentes fitofisionomias no Estado do Paraná. Revista Brasileira de Botânica. 2008; (31): 443-452 p.

BORCARD D, GILLET F, LEGENDRE P. Numerical ecology with R. 1st ed. New York: Springer; 2011.

BUCCI SJ, GOLDSTEIN G, MEINZER FC, FRANCO AC, CAMPANELLO P, SCHOLZ FG. Mechanisms contributing to seasonal homeostasis of minimum leaf water potential and predawn disequilibrium between soil and plant water potential in Neotropical savanna trees. Trees. 2005; 19:296-304.

CARRASCO PG. Produção de Mudas de Espécies Florestais de Restinga em Ilha Comprida (SP). 1st ed. São Paulo: IBT; 2003.

CHAVES LHG, TITO GA, CHAVES IB, LUNA JG, SILVA, PCM. Propriedades químicas do solo aluvial da Ilha de Assunção - Cabrobó (Pernambuco). Revista Brasileira de Ciências do Solo. 2004; 28: 431-437.

CLAUSING G, RENNER SS. Molecular Phyllogenetics of Melastomataceae and Memecylaceae: implications for character evolution. American Journal of Botany. 2001; (88): 486-498.

CLIMATE-DATA. [Internet] Temperatura. [cited 2017 mar 27] Climate-Data.org: Dados climáticos para cidades mundiais. Available from: http://pt.climate-data.org/location/28141/.

EDWARDS CRJ, SANSO G. Characterising sclerophylly: some mechanical properties of leaves from heath and forest. Oecology. 2000; 23:158-167.

EMBRAPA; Empresa Brasileira de Pesquisa Agropecuária. Sistema brasileiro de classificação de solos. 3. ed. Brasília: EMBRAPA; 2013.

EPSTEIN E, BLOOM AJ. Nutrição mineral de plantas: princípios e perspectivas. Rio de Janeiro: Editora Planta; 2006.

ERNANI PR, ALMEIDA JA, SANTOS FC. Potássio. In: Novais RF; Alvarez VH; Barros NF; Fontes RLF; Cantarutti RB; Neves JCL, editors. Fertilidade do solo. Viçosa: SBCS/UFV; 2007. p. 551-594.

FAHN A, CUTLER D.F. Xerophytes. Berlin: Gebrüder Borntraeger; 1992.

FREITAS AVL, COELHO MFB, AZEVEDO RAB, MAIA SSS. Os raizeiros e a comercialização de plantas medicinais em São Miguel, Rio Grande do Norte, Brasil. Revista Brasileira de Biociências. 2012; 2(10):147-156.

GLEASON SM, WESTOBY M, JANSEN S, CHOAT B, HACKE UG, PRATT RB et al. Weak tradeoff between xylem safety and xylem-specific hydraulic efficiency across the world's woody plant species. New Phytol. 2016; 209:123-136.

GRANDA E, CAMARERO JJ, GIMENO TE, FERNANDEZ JM, VALLADARES F. Intensity and timing of warming and drought differentially affect growth patterns of co-occurring Mediterranean tree species. Eur J Forest Res. 2013; 132:469-480. 
GUIMARÃES PJF. [Internet] Tibouchina 2015 [cited 2017 mar 27]. Lista de Espécies da Flora do Brasil. Available from: <http://floradobrasil.jbrj.gov.br/jabot/FB9876>. Jardim Botânico do Rio de Janeiro.

IPPUJ; Fundação Instituto de Pesquisa e Planejamento para o Desenvolvimento Sustentável de Joinville. [Internet] Joinville Cidade em Dados [cited 2017 mar 27]. Available from: http://www.joinville.sc.gov.br/. Prefeitura Municipal de Joinville.

JALEEL CA, MANIVANNAN P, WAHID A, FAROOQ M, AL-JUBURI HJ, SOMASUNDARAM R, PANNEERSELVAM R. Drought Stress in Plants: A Review on Morphological Characteristics and Pigments Composition. International Journal Agricultural Biology. 2009; 100(11):100-105.

JOHANSEN DA. Plant microtechnique. New York: McGraw-Hill; 1940.

KÖPPEN W. Climatologia: con un estudio de los climas de la tierra. Fondo de Cultura Economica.1948:478p.

LAL R. Soil Carbon Sequestration Impacts on Global. Science. 2004; 304:1623p.

LOPES AS, GUILHERME LRG. Interpretação da Análise do Solo - Conceitos e aplicações. São Paulo: ANDA; 2004.

LORENZI H. Árvores brasileiras: manual de identificação e cultivo de plantas arbóreas nativas do Brasil. Nova Odessa: Ed. Plantarum; 1992.

MANTOVANI WA. Vegetação sobre a restinga de Caraguatatuba, SP. In: Congresso Nacional sobre Essências Nativas; 1992 mar/abr 29-3; São Paulo, SP. Revista do Instituto Florestal; 1992. p.139-144.

MELO JÚNIOR JCF, BOEGER MRT. Riqueza, estrutura e interações edáficas em um gradiente de restinga do Parque Estadual do Acaraí, Estado de Santa Catarina, Brasil. Hoehnea. 2015; (42):207-232.

MELO JÚNIOR JCF, BOEGER MRT. Functional Traits of Dominant Plant Species of the Brazilian Sandy Coastal Plain. International Journal of Current Research. 2017; 9(1):45585-45593.

MENDONÇA RR, POMPEIA SL, MARTINS SE. A sucessão secundária da Mata Atlântica na região de Cubatão, SP. In: Congresso Nacional sobre Essências Nativas; 1992 mar/abr 29-3; São Paulo, SP. Revista do Instituto Florestal; 1992. p. 131-144.

MOLES AT, WARTON DI, WARMAN L, SWENSON NG, LAFFAN SW, ZANNE AE, PITMAN A, HEMMINGS FA, LEISHMAN MR. Global patterns in plant height. Journal of Ecology. 2009; 97(5): 835-1116.

MULVANEY MJ, WOOD CW, BALKCOM KS, SHANNON DA, KEMBEL, JM. Carbon and nitrogen mineralization and persistence of organic residues under convervation and conventional tillage. Agron. J. 2010; 102:1425-1433.

NISHIO JN. Why are higher plants green? Evolution of the higher plant photosynthetic pigment complement. Plant. Cell and Environment. 2000; 23:523-548.

PAIVA JGA, FANK-DE-CARVALHO SM, MAGALHÃES MP, GRACIANO-RIBEIRO D. Verniz vitral incolor 500: uma alternativa de meio de montagem economicamente viável. Acta Botanica Brasilica. 2006; (20):257-264.

PENNEYS DS, JUDD WS. Phylogenetics and morphology in the Blakeeae (Melastomataceae). International Journal of Plant Sciences. 2011; 172:78-106.

PIGLIUCCI M. Phenotypic Plasticity: Beyond Nature and Nurture Johns Hopkins University Press. Baltimore. 2001:328p.

POMPÉIA SL, PRADELLA DZA, MARTINS SE, SANTOS RP, DINIZ KM. A semeadura aérea na Serra do Mar, em Cubatão. Revista Cetesb de Tecnologia. 1989; (1):13-19.

PRADO H. Manual de classificação de solos do Brasil. 2nd ed. Piracicaba: FUNEP; 1995. 
PRUDENTE CM, SADER R, BARBOSA JM, SANTOS JUNIOR NA. Produção de sementes e comportamento germinativo de Tibouchina clavata (Pers.) Wurdack. (Melastomataceae). Sci. For. 2012; 40(94):241-248.

PUGNAIRE FI, VALLADARES F. Functional Plant Ecology. New York-London: CRC Press; 2006.

REIS-DUARTE RM. Estrutura da floresta de restinga do parque estadual da ilha Anchieta (SP): bases para promover o enriquecimento com espécies arbóreas nativas em solos alterado [tese]. Rio Claro: Universidade Estadual Paulista/USP; 2004. 230p.

ROMERO R, MARTINS AB. Melastomataceae do Parque Nacional da Serra da Canastra, Minas Gerais, Brasil. Revista Brasileira de Botânica. 2002; 25(1):19-24.

ROMERO R, MONTEIRO R. A família Melastomataceae na planície litorânea de Picinguaba, Parque Estadual da Serra do Mar, município de Ubatuba, SP. Naturalia. 1995; 20:227-239.

ROMERO R, MONTEIRO R. Ocorrência da família Melastomataceae na planície litorânea de Picinguaba, município de Ubatuba, São Paulo. In: simpósio sobre Ecossistemas da Costa Brasileira; 1993, abr 2-7; São Paulo, SP. São Paulo: ACIESP; 1994. p.115-123.

ROMERO R. A familia Melastomataceae na Estação Ecológica do Panga, município de Uberlândia, Minas Gerais. Hoehnea. 1996; 23:147-168.

ROMERO, R. Diversidade da flora dos campos rupestres de Goiás, sudoeste e sul de Minas Gerais. In: Araújo EL, Moura AN, Sampaio EVSB, Gestinari LM, Carneiro JMT, editors. Biodiversidade, conservação e uso sustentável da flora do Brasil. Recife: UFRP; 2002. p. 200-253.

RENNER SS. Phylogeny and classification of the Melastomataceae and Memecylaceae. Nordic journal of Botany. 1993; 13: 519-540.

RONQUIM CC. Conceitos de fertilidade do solo e manejo adequado para as regiões tropicais. Campinas: EMBRAPA; 2010.

ROSADO BHP, DE MATTOS EA. Interspecific variation of functional traits in a CAM-tree dominated sandy coastal plain. Journal of Vegetation Science. 2010; 21:43-54.

RYAN MG, PHILLIPS N, BOND BJ. The hydraulic limitation hypothesis revisited. Plant, Cell and Environment. $2006 ; 29: 367-381$.

SANTOS R, ELIAS GA, GUISLON A, ZANONI IZ. Vegetação arbustivo-arbórea em uma restinga de Jaguaruna, litoral sul do Estado de Santa Catarina, Brasil. Rev. Ambient. Água. 2017;12(1):99-111.

SCHLICHTING CD, WUND MA. Phenotypic plasticity and epigenetic marking: an assessment of evidence for genetic accommodation. Evolution. 2014; 68(3):656-672.

SCHLICHTING CD. 1986. The evolution of phenotypic plasticity in plants. Annual Review in Ecology and Systematics. 1986; 17:667-693.

SCHLICHTING CD. Phenotypic plasticity in plants. Plant Species Biology. 2002; 17:85-88.

SIBALDELLI RNR, CARVALHO JFC, OLIVEIRA MCN. Uso de geoestatística no estudo da variabilidade espacial da capacidade de troca de cátions do solo. Gl. Sci Technol. 2015; 08(1):141 - 156.

SILVA KR, MELO JR JCF, BOEGER MRT. Variações fenotípicas em Andira fraxinifolia Benth. (Fabaceae) em duas fitofisionomias de restinga. Hoehnea. 2016; 43(2): 229-237.

SILVA MM, MELO JÚNIOR, JCF. Composição florística e estrutural de uma comunidade herbáceo-arbustiva de restinga em Balneário Barra do Sul, Santa Catarina. Revista Brasileira de Biociências. 2016; 14(4):207-214. 
TODZIA CA, ALMEDA F. A revision of Tibouchina section Lepidotae (Melastomataceae: Tibouchineae).

Proceedings of the California Academy of Sciences. 1991; 47:175-206.

TURNER JM. Sclerophylly: primarily protective? Functional Ecology. 1994; 8:669-675.

VALLADARES F, SANCHES-GOEMS D, ZAVALA MA. Quantitative estimation of phenotypic plasticity: bridging the gap between the evolutionary concept and its ecological applications. Journal of Ecology. 2006; 94:1103-1116.

WITKOWSKI ETF, LAMONT BB. Leaf specific mass confounds leaf density and thickness. Oecologica. 1991; 88:486-493.

WUND MA. Assessing the Impacts of Phenotypic Plasticity on Evolution. Integrative and Comparative Biology. 2012; 52:5-15.

WURDACK JJ. Melastomataceae of Santa Catarina. Sellowia. 1962; 14:109-217.

ZAMITH LR, SCARANO FR. Produção de mudas de espécies das Restingas do município do Rio de Janeiro, RJ, Brasil. Acta Botanica Brasilica. 2004; 18(1)161-176.

ZAR JH. Biostatistical analysis. $4^{\text {th }}$ ed. New Jersey: Prentice-Hall Inc; 1999. 